\title{
Antimicrobial Activity of 3,4-seco-Diterpenes Isolated from Croton blanchetianus against Streptococcus mutans and Streptococcus parasanguinis
}

\author{
Nairley C. S. Firmino, ${ }^{a}$ Francisco S. O. Alexandre, ${ }^{b}$ Mayron A. de Vasconcelos, ${ }^{a, c}$ Alison J. S. Conrado, ${ }^{a}$ \\ Francisco V. S. Arruda, ${ }^{a}$ Edilberto R. Silveira ${ }^{*, b}$ and Edson H. Teixeira ${ }^{*, a}$ \\ ${ }^{a}$ Laboratório Integrado de Biomoléculas, Departamento de Patologia e Medicina Legal, \\ Universidade Federal do Ceará, 60430-270 Fortaleza-CE, Brazil \\ ${ }^{b}$ Departamento de Química Orgânica e Inorgânica, Centro de Ciências, \\ Universidade Federal do Ceará, CP 12.200, 60021-940 Fortaleza-CE, Brazil \\ 'Departamento de Ciências Biológicas, Faculdade de Ciências Exatas e Naturais, \\ Universidade do Estado do Rio Grande do Norte, 59625-620 Mossoró-RN, Brazil
}

\begin{abstract}
In this study, acid and neutral fractions and three diterpenes were isolated from the hexane extracts from roots of three individual specimens of Croton blanchetianus Baill., collected from the same geographical site. Moreover, the antimicrobial activity of the extracts, fractions and diterpenes isolated was evaluated against Streptococcus mutans and Streptococcus parasanguinis, bacteria related with dental caries. The structures of the diterpenes were elucidated mainly by $1 \mathrm{D}$ and $2 \mathrm{D}$ nuclear magnetic resonance (NMR) spectroscopy, and high-resolution mass spectrometry, such as methyl 12-hydroxy-3,4-seco-cleistanta-8,11,13,15,4(18)-pentaene-3-oate; ent-3,4-secoatisa4(18),16-dien-3-oic acid and a novel diterpene 3,4-seco-beieren-3-oic acid. Regarding to the antimicrobial activity, in general, all extracts, the neutral and acid fractions of the hexane extracts roots of all three specimens, showed antimicrobial activity in concentrations ranging from 500 to $7.8 \mu \mathrm{g} \mathrm{mL}^{-1}$. In addition, the three diterpenes isolated showed bactericidal and bacteriostatic activity against $S$. mutans and $S$. parasanguinis, suggesting them as alternative agents with the potential to prevent oral diseases.
\end{abstract}

Keywords: seco-diterpenes, Euphorbiaceae, Croton blanchetianus, oral biofilm

\section{Introduction}

The genus Croton (Euphorbiaceae) comprises about 1300 species, which inhabit tropical and subtropical regions around the world. In Brazil, plants belonging to the Croton genus are found abundantly in the northeast area. The use of plants belonging to this genus, in folk medicine, includes treatments for cancer, constipation, diabetes, digestive problems, dysentery, external wounds, fever, hypercholesterolemia, hypertension, inflammation, intestinal worms, malaria, pain, ulcers and weight loss. ${ }^{1}$

Many species of Croton have strong economic potential, especially for the pharmaceutical industry, due to the various secondary metabolites that, according to many studies, are responsible for the therapeutic properties of them. ${ }^{2}$ Pirani, a Brazilian botanist, has defined Croton as a "problem genus", mainly because of its large size and taxonomic complexity. ${ }^{3}$ According to

*e-mail: edil@ufc.br; edson@ufc.com
The Plant List, C. micranthus Müell. Arg., ${ }^{4}$ C. persicaria Baill., ${ }^{5}$ and Oxydectes blanchetiana (Baill.) Kunte, ${ }^{6}$ are synonyms for $C$. blanchetianus, but other Brazilian botanists have reported C. alagoensis Müell. Arg. and C. floribundus var. piauhyensis Rizzini as other synonyms as well..$^{7-9}$ In the past, our research group has devoted a large effort on phytochemical studies of the same plant species mistakenly identified, at that time, as $C$. sonderianus Müell. Arg. ${ }^{7-9}$ Nowadays, that plant species has been correctly identified as $C$. blanchetianus Baill., and a few reports mention that $C$. sonderianus and $C$. blanchetianus are indeed synonyms. ${ }^{10,11}$

Several biological activities of Croton species have been reported, among them: the antimalarial action and low acute and subacute toxicity of the leaf extract of Croton macrostachyus, ${ }^{1}$ the inhibition of chikungunya virus replication by Croton mauritianus leaf extract, ${ }^{12}$ the antiulcerogenic action and the low acute and subacute toxicity of Croton urucurana extract. ${ }^{13}$ Ethanol extracts of the trunks, leaves, and seeds of Croton tiglium showed 
some antifungal activities against three dermatophytes. The ethanol extracts of trunk or seed of $C$. tiglium exhibit strong antidermatophytic activities and, thus, could be considered for application on treating skin fungal infections after appropriate processing. ${ }^{14}$

The hydroalcoholic extract from leaves of C. macrostachyus demonstrated antimicrobial action against isolated clinical bacteria of interest to the veterinarian. ${ }^{15}$ The hydroalcohol, hexane and ethanol extracts from leaves of Croton doctoris showed relevant activity against caries-related bacteria: Actinomyces naeslundii, Lactobacillus acidophilus, Streptococcus gordonii, S. mutans, Streptococcus sanguinis, Streptococcus sobrinus and Streptococcus mitis. Analysis of the composition of the extract showed that there are large amounts of phenol compounds and diterpenes. ${ }^{16}$ Croton roxburghii extract demonstrated significant antimicrobial activity against clinical isolates of Bacillus cereus and Shigella flexneri, strains of Staphylococcus aureus, Escherichia coli, Salmonella spp., Shigella dysentriae, and Vibrio cholerae. ${ }^{17}$

The crude polysaccharide fraction, obtained from the hot aqueous extract of Croton cajucara leaves, was able to promote gastroprotection. It was able to reduce ethanol-induced gastric ulcers in rats, ${ }^{18}$ the antinociceptive and pro-healing activity of Croton adamantinus essential oil was seen in rats, ${ }^{19}$ the nanoparticles synthesized from the leaf extract of Croton sparsiflorus showed significant antimicrobial activity against $S$. aureus, E. coli and Bacillus subtilis. ${ }^{20}$ Diterpenoids from $C$. tonkinensis showed a high antituberculosis activity against Mycobacterium tuberculosis, ${ }^{21}$ the ent-kaurane diterpene of Croton tonkinensis showed the induction of apoptosis in colorectal cancer cells, ${ }^{22}$ and the diterpenes isolated from $C$. cajucara exhibited an antileishmanial action. $^{23}$

C. blanchetianus Baill., popularly known as "marmeleiro preto", is found in the Brazilian semi-arid region. There are botanical synonyms like Croton sonderianus Müll. Arg. and Croton alagoensis Müll. Arg. ${ }^{3,11,24}$ Distributed at the Caatinga biome, it can be found in several places, with relatively low height and diameters and a significant number of representatives. It is widely used by rural populations, mainly for the production of firewood and the construction of small corral to house animals. ${ }^{25}$

Studies have shown that isolated compounds and the essential oil of $C$. blanchetianus present antinociceptive activity $^{26}$ and insecticidal activity against Aedes aegypti. ${ }^{27}$ The hydroalcoholic extract of $C$. blanchetianus bark showed acaricidal activity, ${ }^{28}$ antibacterial and antifungal properties. ${ }^{7-9}$ In addition, the essential oil has been found useful to inhibit the growth of pathogenic microorganisms in foods. ${ }^{29}$ Considering that extracts from C. blanchetianus were able to inhibit the growth of microorganisms, the objective of this study was to isolate and characterize the compounds responsible for the antimicrobial action on bacteria related to the development of dental caries.

\section{Experimental}

Infrared (IR) spectra were recorded on a PerkinElmer spectrometer, Spectrum 100 FTIR, equipped with universal attenuated total reflectance accessory (UATR). ${ }^{1} \mathrm{H}$ and ${ }^{13} \mathrm{C}$, $1 \mathrm{D}$ and $2 \mathrm{D}$ nuclear magnetic resonance (NMR) spectra were obtained either on a Bruker Avance DRX-500 (500 MHz to ${ }^{1} \mathrm{H}$ and $125 \mathrm{MHz}$ to ${ }^{13} \mathrm{C}$ ) or Avance DPX-300 spectrometers (300 MHz to ${ }^{1} \mathrm{H}$ and $75 \mathrm{MHz}$ to ${ }^{13} \mathrm{C}$ ). High resolution mass spectra (HRMS) were performed on an LCMS-IT-TOF (225-07100-34, Shimadzu), equipped with electrospray ionization (ESI) source either on positive or negative mode.

The separation, and compounds purification was carried out on a Waters HPLC, consisting of a binary pump (Waters-1525) and a PDA UV detector (Waters-2996),

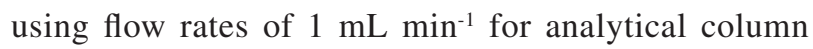
$(4.6 \times 250 \mathrm{~mm}, 5 \mu \mathrm{m})$ and $4.72 \mathrm{~mL} \mathrm{~min}^{-1}$ for semi-preparative column $(10 \times 250 \mathrm{~mm}, 5 \mu \mathrm{m})$. In the gravitational adsorption chromatography, silica gel 60 (70-230 mesh, Vetec) was used, while Sephadex LH-20 (Pharmacia) was used in the chromatographic fractionation by molecular exclusion. Thin layer chromatography (TLC) was performed on precoated silica gel aluminum sheets (5-40 mesh, Merck) with fluorescence indicator in the range of $254 \mathrm{~nm}$ (F254). The substances were revealed by spraying with a vanillinperchloric acid/EtOH solution, followed by heating in an oven (ca. $100^{\circ} \mathrm{C}$ ) for $5 \mathrm{~min}$.

\section{Sample preparation, strains and culture conditions}

For the antimicrobial assays, solutions containing extracts, fractions and diterpenes isolated from C. blanchetianus, were prepared in culture medium BHI (brain heart infusion) broth with $8 \%$ dimethyl sulfoxide (DMSO). The microorganisms used in this study were S. mutans (UA159) and S. parasanguinis (ATCC903). Bacteria were cultured from a stock culture in BHI broth containing $20 \%$ glycerol. An aliquot of $20 \mu \mathrm{L}$ of each of the bacterium was inoculated into Petri dishes containing $\mathrm{BHI}$ agar medium and incubated at $37{ }^{\circ} \mathrm{C}$ for $24 \mathrm{~h}$ with $5 \% \mathrm{CO}_{2}$. Next, isolated colonies were inoculated into $10 \mathrm{~mL}$ of sterile BHI broth and incubated under the same conditions previously mentioned. After antimicrobial assays, the bacterial culture was adjusted to a concentration of $2 \times 10^{6}$ colony-forming unit (CFU) $\mathrm{mL}^{-1}$. 
Minimum inhibitory concentration and minimum bactericidal concentration determination

The minimum inhibitory concentration (MIC) was determined by microdilution tests on polystyrene plates, standardized according to the NCCLS (present CLSI), approved standard $\mathrm{M} 7-\mathrm{A} 6,{ }^{30}$ with modifications. In the 96-well polystyrene plates, the substance was serially diluted until the obtained concentrations were ranging from 125 to $1.8 \mu \mathrm{g} \mathrm{mL} \mathrm{m}^{-1}$. One hundred microliters of each bacterial suspension was added to the plate containing the substances, resulting in a final volume of $200 \mu \mathrm{L}$ per well. The plates were then incubated for $24 \mathrm{~h}$ at $37{ }^{\circ} \mathrm{C}$ in an atmosphere containing $5 \% \mathrm{CO}_{2}$. After $24 \mathrm{~h}$, the evaluation of bacterial growth was determined by visualizing the turbidity of the culture medium. The presence of turbidity meant that the substance did not inhibit microbial growth. In addition, the bacterial growth was measured by determining the optical density at $620 \mathrm{~nm}$ by using a microplate reader (SpectraMax i3 Multi-Mode microplate reader). In this way, the MIC was considered as the lowest concentration showing complete inhibition of visible bacterial growth. The negative control consisted of $8 \%$ DMSO in BHI culture medium and chlorhexidine gluconate was used as positive control.

Regarding minimum bactericidal concentration (MBC) determination, $10 \mu \mathrm{L}$ of the bacterial suspension in the MIC were incubated in Petri dishes containing BHI agar. The plates were maintained at $37^{\circ} \mathrm{C}$ and $5 \% \mathrm{CO}_{2}$ for $24 \mathrm{~h}$ and, after this time, bacterial growth was evaluated. $\mathrm{MBC}$ was considered the lowest concentration that no colony growth was observed.

\section{Plant material}

On February 2012, in the locality of Garapa, located in the municipality of Acarape, CE, Brazil, the leaves and inflorescences of eight individual specimens of C. blanchetianus were collected. After, it was analyzed the ${ }^{1} \mathrm{H}$ NMR spectra of leaf and inflorescences essential oils of these eight specimens of $C$. blanchetianus, showing different chemical profiles. These differences were used as criteria for the selection of three specimens, designated CB1, CB4 and CB8, for the study. On April of the same year, roots, heartwood and trunk bark of the three specimens of C. blanchetianus were harvested.

The authentication of the plant material was carried out by MSc Maria Lenise Guedes of the Instituto de Biologia (Universidade Federal da Bahia). The voucher specimens (No. 53043, 53045 and 53047) are deposited in the Herbarium Prisco Bezerra (EAC) of the Universidade Federal do Ceará.

\section{Extraction and isolation}

The extracts of hexane from roots (RCB), heartwood (WCB) and trunk bark (BCB) from three specimens of $C$. blanchetianus were produced. $100.0 \mathrm{~g}$ of the entire roots, heartwood or trunk bark of CB1, CB4 and CB8, after drying and crushing, were individually subjected to maceration in hexane for $24 \mathrm{~h}(3 \times 0.5 \mathrm{~L})$. The hexane solutions were pooled, and then evaporated under reduced pressure to obtain the hexane extracts from roots $(\mathrm{RCB} 1=4.44 \mathrm{~g}, \mathrm{RCB} 4=7.09 \mathrm{~g}$ and $\mathrm{RCB} 8=5.36 \mathrm{~g})$, heartwood $(\mathrm{WCB} 1=2.36 \mathrm{~g}$, WCB4 $=3.80 \mathrm{~g}$ and $\mathrm{WCB} 8=2.94 \mathrm{~g})$, and trunk bark $(\mathrm{BCB} 1=8.42 \mathrm{~g}$, $\mathrm{BCB} 4=8.91 \mathrm{~g}$ and $\mathrm{BCB} 8=6.82 \mathrm{~g}$ ). From the initial results of the microbiological tests performed with these extracts (Table 1), it was decided to perform the phytochemical analysis of the root extracts.

The procedure was then repeated with $2.5 \mathrm{~kg}$ of roots by maceration in hexane for $72 \mathrm{~h}(3 \times 7.0 \mathrm{~L})$. The hexane solutions were evaporated under reduced pressure to yield the respective extracts RCB1 (73.13 g, 2.93\%), RCB4 (116.08 g, 4.64\%), and RCB8 (75.13 g, 3.00\%).

$10.0 \mathrm{~g}$ of RCB1 were solubilized in $\mathrm{CH}_{2} \mathrm{Cl}_{2}$, adsorbed onto $100.0 \mathrm{~g}$ of silica gel, added to a column $(8.0 \times 50.0 \mathrm{~cm})$ of $40.0 \mathrm{~g}$ of silica gel. 18 fractions (A1-A18) of $225 \mathrm{~mL}$ were collected by elution with: hexane (A1-A3), hexane/ $\mathrm{CH}_{2} \mathrm{Cl}_{2}$ 1:1 (A4-A8), $\mathrm{CH}_{2} \mathrm{Cl}_{2}$ (A9-A13), EtOAc (A14-A15), and finally $\mathrm{MeOH}$ (A16-A18). After concentration and TLC analysis, similar fractions were pooled together. $680.0 \mathrm{mg}$ of fraction A9 were solubilized in $\mathrm{CH}_{2} \mathrm{Cl}_{2}$, adsorbed on $1.0 \mathrm{~g}$ silica gel and chromatographed on a column $(3.0 \times 50.0 \mathrm{~cm})$ of $10.0 \mathrm{~g}$ silica gel. Fractions were collected with the following volumes: B1-B53, $10 \mathrm{~mL}$; and B54-B61, $50 \mathrm{~mL}$. The eluents used were: hexane (B1-B8), hexane/ $\mathrm{CH}_{2} \mathrm{Cl}_{2} 25 \%$ (B9-B27), hexane/ $\mathrm{CH}_{2} \mathrm{Cl}_{2}$ 1:1 (B28-B56), $\mathrm{CH}_{2} \mathrm{Cl}_{2}$ (B57), EtOAc (B58) and $\mathrm{MeOH}$ (B59-B61). After rotaevaporation under reduced pressure and TLC analysis, similar fractions B34-B37 (104.2 mg) were pooled, resulting in a colorless resin named ICB1.

${ }^{1} \mathrm{H}$ NMR analysis of ICB1 revealed its carboxylic acid character, then another approach was designed. $10.0 \mathrm{~g}$ of RCB1 were dissolved in $100 \mathrm{~mL}$ of $2 \% \mathrm{KOH} / \mathrm{MeOH}$ solution, stirred at room temperature (ca. $25^{\circ} \mathrm{C}$ ) for $4 \mathrm{~h}$ and then rotaevaporated under vacuum to half of its volume (50 mL). Moreover, $100 \mathrm{~mL}$ of distilled $\mathrm{H}_{2} \mathrm{O}$ was added and then extracted with $\mathrm{CH}_{2} \mathrm{Cl}_{2}(100,50$ and $50 \mathrm{~mL})$. The final solution of all organic phases together was washed with distilled $\mathrm{H}_{2} \mathrm{O}(3 \times 50 \mathrm{~mL})$, dried with anhydrous $\mathrm{Na}_{2} \mathrm{SO}_{4}$, filtered and rotaevaporated under vacuum, providing a viscous liquid material called NFCB1 (2.64 g). The hydromethanol phase was acidified with aqueous $\mathrm{HCl}$ 
Table 1. MIC and MBC values of the hexane extracts from roots, heartwood and trunk bark of CB1, CB4 and CB8 on S. mutans and S. parasanguinis

\begin{tabular}{|c|c|c|c|c|}
\hline \multirow{2}{*}{ Hexane extract } & \multicolumn{2}{|c|}{ S. mutans } & \multicolumn{2}{|c|}{ S. parasanguinis } \\
\hline & $\mathrm{MIC} /\left(\mu \mathrm{g} \mathrm{mL}^{-1}\right)$ & $\mathrm{MBC} /\left(\mu \mathrm{g} \mathrm{mL}^{-1}\right)$ & $\mathrm{MIC} /\left(\mu \mathrm{g} \mathrm{mL}^{-1}\right)$ & $\mathrm{MBC} /\left(\mu \mathrm{g} \mathrm{mL}^{-1}\right)$ \\
\hline $\mathrm{RCB} 1$ & 15.6 & 250 & 31.2 & 62.5 \\
\hline WCB1 & 62.5 & - & 62.5 & 125 \\
\hline BCB1 & 31.2 & - & 62.5 & 125 \\
\hline RCB4 & 31.2 & 250 & 31.2 & 250 \\
\hline WCB4 & 250 & - & 62.5 & 250 \\
\hline BCB4 & 62.5 & - & 62.5 & - \\
\hline RCB8 & 31.2 & - & 31.2 & - \\
\hline WCB8 & 250 & - & 125 & 250 \\
\hline BCB8 & 31.2 & 62.5 & 62.5 & 250 \\
\hline
\end{tabular}

RCBx: C. blanchetianus roots; WCBx: C. blanchetianus heartwood; BCBx: C. blanchetianus trunk bark; $\mathrm{x}=1$ for specimen $1, \mathrm{x}=4$ for specimen 4 , and $\mathrm{x}=8$ for specimen 8 . MIC: minimum inhibitory concentration; MBC: minimum bactericidal concentration.

(5\%) to $\mathrm{pH} 1$, and then extracted with $\mathrm{CH}_{2} \mathrm{Cl}_{2}$ (100, 50 and $50 \mathrm{~mL}$ ). After pooled, the organic phases gave a solution which was washed with distilled $\mathrm{H}_{2} \mathrm{O}(3 \times 50 \mathrm{~mL})$ until $\mathrm{pH} 7$, dried with anhydrous $\mathrm{Na}_{2} \mathrm{SO}_{4}$ and rotaevaporated under vacuum to give the acidic fraction AFCB1 $(6.52 \mathrm{~g})$.

This procedure was repeated for RCB4, resulting in $2.77 \mathrm{~g}$ of NFCB4 and $6.85 \mathrm{~g}$ of AFCB4, as well as for $\mathrm{RCB} 8$, resulting in $5.22 \mathrm{~g}$ of NFCB8 and $3.64 \mathrm{~g}$ of AFCB8.

The non acidic fractions NFCB1, NFCB4 and NFCB8 were individually solubilized in $\mathrm{CH}_{2} \mathrm{Cl}_{2}$ and pre-adsorbed on silica gel, corresponding to 10 times the mass of each fraction. Twelve fractions of $250 \mathrm{~mL}$ were collected for NFCB1 and NFCB4, and 18 fractions for NFCB8 (see Table S1, Supplementary Information (SI) section). This procedure was repeated for the AFCB1, AFCB4 and AFCB 8 acid fractions. 11 fractions of $250 \mathrm{~mL}$ were collected for each column $(8.0 \times 50.0 \mathrm{~cm})$ with $70.0 \mathrm{~g}$ of silica gel (Table S2, SI section). $200.0 \mathrm{mg}$ of the NFCB4 fraction were subjected to HPLC (high performance liquid chromatography) on a semi-preparative silica gel column with hexane/EtOAc (30\% v/v) as the isocratic mobile phase. $20.1 \mathrm{mg}$ of a yellow resin designated ICB4 (retention time $\left(\mathrm{t}_{\mathrm{R}}\right)=4.42 \mathrm{~min}$ ) was obtained.

$3.64 \mathrm{~g}$ of AFCB8 were adsorbed onto silica gel $(37.0 \mathrm{~g})$ packed over a column $(5.0 \times 50.0 \mathrm{~cm})$ of $25.0 \mathrm{~g}$ silica gel. Eleven fractions (D1-D11) of $250 \mathrm{~mL}$ were collected by elution with: hexane (D1), hexane $/ \mathrm{CH}_{2} \mathrm{Cl}_{2}$ 1:1 (D2-D3), $\mathrm{CH}_{2} \mathrm{Cl}_{2}$ (D4-D6), $\mathrm{CH}_{2} \mathrm{Cl}_{2} /$ EtOAc 25\% (D7D8), EtOAc (C9), EtOAc/MeOH 1:1 (D10) and $\mathrm{MeOH}$ (D11). $370 \mathrm{mg}$ of D4 were solubilized in $\mathrm{MeOH}$ and chromatographed on a column $(4.0 \times 50.0 \mathrm{~cm})$ of $27.0 \mathrm{~cm}$ of Sephadex LH-20 dextran gel. The first fraction (D1) was collected after elution of $100 \mathrm{~mL}$ of $\mathrm{MeOH}$, using a mean flow of 12 drops $\mathrm{min}^{-1}$, and then twenty fractions
(E1-E20) of $8.0 \mathrm{~mL}$ were collected. The E10 fraction after rotaevaporation and TLC analysis resulted in $113.0 \mathrm{mg}$ of a colorless resin named ICB8.

\section{Results and Discussion}

The compound ICB1, a colorless resin displayed an HRESIMS ion at $\mathrm{m} / \mathrm{z} 303.2321[\mathrm{M}+\mathrm{H}]^{+}$(calcd. for $\mathrm{C}_{20} \mathrm{H}_{31} \mathrm{O}_{2}, 303.2324$ ) or 301.2157 [M - H] (calcd. for $\left.\mathrm{C}_{20} \mathrm{H}_{29} \mathrm{O}_{2}, 301.2168\right)$ in its HRESIMS spectra, $[\alpha]_{D}^{21}+18.2^{\circ}$ (c $0.11, \mathrm{CHCl}_{3}$ ). Its IR spectrum showed characteristic absorptions of $\mathrm{O}-\mathrm{H}$ stretching of carboxylic acid (3400 to $2400 \mathrm{~cm}^{-1}$ ) and also $\mathrm{C}=\mathrm{O}$ stretching at $1705 \mathrm{~cm}^{-1}$. It also showed absorptions at $1635 \mathrm{~cm}^{-1}$ of $\mathrm{C}=\mathrm{C}$ stretching and $745 \mathrm{~cm}^{-1}$ of out-of-plane $=\mathrm{C}-\mathrm{H}$ bending. The ${ }^{1} \mathrm{H}$ NMR spectrum of compound ICB1 (Table 2) revealed the presence of protons of a cis and of a terminal carbon-carbon double bonds at $\delta_{\mathrm{H}} 5.72(\mathrm{~d}, J 5.0 \mathrm{~Hz}, \mathrm{H}-15), 5.49(\mathrm{~d}$, $J 5.0 \mathrm{~Hz}, \mathrm{H}-16$ ), 4.87 (s, H-18a) and 4.68 (s, H-18b). Three singlets related to methyl protons at $\delta_{\mathrm{H}} 0.77(\mathrm{H}-20), 1.01$ (H-17) and 1.75 (H-19) were also observed. The latter one is characteristic of an isopropenyl group, while the other two seem to be attached to quaternary carbons. The ${ }^{13} \mathrm{C}$ NMR-BB (broad-band) spectrum of compound ICB1 (Table 2) presented 20 spectral lines with the signal at $\delta_{\mathrm{C}} 180.8$ (C-3) referring to an acid carboxyl, the signals at $\delta_{\mathrm{C}} 147.7(\mathrm{C}-4), 113.8(\mathrm{C}-18)$ and 23.9 (C-19) corresponding to the isopropenyl group, as well as two other olefinic carbons at $\delta_{\mathrm{C}} 134.8(\mathrm{C}-15)$ and $137.0(\mathrm{C}-16)$. Comparison of the $\mathrm{BB}$ and distortionless enhancement of polarization transfer (DEPT) $135^{\circ}{ }^{13} \mathrm{C}$ NMR spectra permitted to identify the hydrogenation pattern of each carbon of compound ICB1, confirming its molecular formula $\mathrm{C}_{20} \mathrm{H}_{30} \mathrm{O}_{2}$, indicating 6 double bond equivalents (DBE's), 
from which three were related to three rings, two carboncarbon double bonds and a carboxyl. The ${ }^{1} \mathrm{H},{ }^{1} \mathrm{H}-\mathrm{COSY}$ (correlation spectroscopy) spectrum analysis evidenced the correlations for the olefinic protons at $\delta_{\mathrm{H}} 5.72(\mathrm{~d}, J 5.0 \mathrm{~Hz}$, $\mathrm{H}-15)$ and 5.49 (d, J 5.0 Hz, H-16). The presence of the isopropenyl group was confirmed through the correlation of the protons of the methyl carbon at $\delta_{\mathrm{H}} 1.75(\mathrm{~s}, \mathrm{H}-19)$ with the protons of the methylidene carbon at $\delta_{\mathrm{H}} 4.87$ (s, H-18a) and $\delta_{\mathrm{H}} 4.68$ (s, H-18b). The two dimensional ${ }^{1} \mathrm{H},{ }^{13} \mathrm{C}-\mathrm{HMBC}$ (heteronuclear multiple bond correlation) spectrum revealed the presence of the isopropenyl group attached to carbon $\mathrm{C}-5$, which was confirmed through the correlations of the terminal vinyl protons at $\delta_{\mathrm{H}} 4.87$ (s, H-18a) and 4.68 (s, H-18b) with the carbons at $\delta_{\mathrm{C}} 147.7$ (C-4), 51.3 (C-5) and 23.9 (C-19). The presence of the C-17 methyl linked to carbon $\mathrm{C}-13$ was confirmed through the correlations observed for the protons of C-17 at $\delta_{\mathrm{H}} 1.01$ (s, $3 \mathrm{H})$, with the carbons at $\delta_{\mathrm{C}} 44.1$ (C-13), 61.3 (C-14), 33.3 (C-12), and 137.0 (C-16). The cis olefinic system (C-15, $\mathrm{C}$-16) was ratified through the HMBC correlations of the protons at $\delta_{\mathrm{H}} 5.72(\mathrm{~d}, J 5.0 \mathrm{~Hz}, \mathrm{H}-15)$ and $5.49(\mathrm{~d}, J 5.0 \mathrm{~Hz}$, $\mathrm{H}-16)$ with the carbons at $\delta_{\mathrm{C}} 44.1$ (C-13), 61.3 (C-14) and 49.1 (C-8). The relative stereochemistry was defined based on the ${ }^{1} \mathrm{H},{ }^{1} \mathrm{H}-\mathrm{NOESY}$ (nuclear Overhauser effect spectroscopy) spectrum by the dipolar coupling correlation of the proton at $\delta_{\mathrm{H}} 1.99(\mathrm{H}-5)$ with the proton at $\delta_{\mathrm{H}} 1.14$ (H-9). The correlations for the protons of methyl C-20 at $\delta_{\mathrm{H}} 0.77(\mathrm{~s}, 3 \mathrm{H})$ with the protons at $\delta_{\mathrm{H}} 5.72(\mathrm{~d}, J 5.0 \mathrm{~Hz}$, $\mathrm{H}-15), 1.81$ (d, J $12.8 \mathrm{~Hz}, \mathrm{H}-11 \mathrm{a})$ and 4.68 (s, H-18b) allowed the determination of the relative configurations at the stereogenic centers $\mathrm{C}-8, \mathrm{C}-10$ and $\mathrm{C}-13$. It is possible to conclude that the compound ICB 1 is the unknown diterpene 3,4-seco-beieren-3-oic acid (Figure 1). Compound ICB1 is the "3,4-seco" counterpart of the ent-Beyer-15-en-18-oic acid, previously isolated from $C$. sonderianus. ${ }^{31}$

The ${ }^{1} \mathrm{H}$ NMR spectrum of compound ICB4 (Table 2) revealed the presence of olefinic protons of a vinyl moiety at $\delta_{\mathrm{H}} 6.73(\mathrm{dd}, J 11.4,18.0 \mathrm{~Hz}, \mathrm{H}-15), 5.57$ (dd, J 2.0, $11.4 \mathrm{~Hz}$, $\mathrm{H}-16 \mathrm{a}$ ), and 5.26 (dd, J 2.0, $18.0 \mathrm{~Hz}, \mathrm{H}-16 \mathrm{~b})$, in addition to signals at 4.99 (s, H-18a) and 4.84 (s, H-18b), characteristic of the methylidene protons of a terminal carbon-carbon double bond, as observed for ICB4. There were also three singlets related to methyl protons at $\delta_{\mathrm{H}} 1.24(\mathrm{~s}, \mathrm{H}-20), 1.77$ (s, H-19) and 2.52 (s, H-17), and another singlet related to a methoxyl at $\delta_{\mathrm{H}} 3.56$. The ${ }^{13} \mathrm{C}$ NMR-BB spectrum of ICB4 (Table 2) presented 21 spectral lines, from which the signal at $\delta_{\mathrm{C}} 174.8(\mathrm{C}-3)$ was assigned to an ester carbonyl and the signals at $\delta_{\mathrm{C}} 155.8(\mathrm{C}-12), 139.7$ (C-14), 142.0 (C-9), 126.3 (C-8), 121.6 (C-13), and 112.5 (C-11), to the carbons of a penta-substituted benzene ring. In addition, four olefinic carbons at $\delta \mathrm{c} 147.9(\mathrm{C}-4)$ and $114.9(\mathrm{C}-18)$ of the terminal double bond, 137.0 (C-15) and 119.9 (C-16), characteristic of the vinyl moiety, were also characterized. Comparison of the BB and the DEPT $135^{\circ}{ }^{13} \mathrm{C}$ NMR spectra permitted to identify the hydrogenation pattern of ICB4, confirming the molecular formula $\mathrm{C}_{21} \mathrm{H}_{28} \mathrm{O}_{3}$, presenting 6 DBE's. Its IR spectrum showed an intense absorption characteristic of $\mathrm{C}=\mathrm{O}$ at $1730 \mathrm{~cm}^{-1}$, compatible with an ester carbonyl. A broad band centered at $3420 \mathrm{~cm}^{-1}$, characteristic of $\mathrm{O}-\mathrm{H}$; an absorption at $3050 \mathrm{~cm}^{-1}$, characteristic of benzene $\mathrm{C}-\mathrm{H}$ stretching; besides absorptions at 1600 and $1480 \mathrm{~cm}^{-1}$ for the skeletal bands; at $1650 \mathrm{~cm}^{-1}$, with a shoulder, of the $\mathrm{C}=\mathrm{C}$ stretching of alkenes, were also observed. Comparison of the ${ }^{1} \mathrm{H}$ and ${ }^{13} \mathrm{C}$ NMR-BB spectra with data from the literature, ${ }^{4}$ allowed to identify compound ICB4 as the methyl 12-hydroxy-3,4-seco-cleistanta8,11,13,15,4(18)-pentaene-3-oate, a diterpene, previously isolated from $C$. sonderianus (Figure 1). ${ }^{4}$

Compound ICB 8 showed a ${ }^{13} \mathrm{C}$ NMR-BB spectrum with 20 spectral lines (Table 2). Comparison of the $\mathrm{BB}$ and DEPT $135^{\circ}{ }^{13} \mathrm{C}$ NMR spectra permitted to establish the hydrogenation pattern of each carbon atom, as 2 methyls, 8 methylenes and 2 methylidenes, and 5 non-hydrogenated carbons, with the molecular formula $\mathrm{C}_{20} \mathrm{H}_{30} \mathrm{O}_{2}$, indicating 6 DBE's. The ${ }^{1} \mathrm{H}$ NMR spectrum of ICB8 (Table 2) showed signals at $\delta_{\mathrm{H}} 4.96$ (s, H-18a), 4.89 (s, H-17a), 4.87 (s, H-18b) and 4.72 (s, H-17b) corresponding to terminal double bond protons, and 2 singlets for two methyl at $\delta_{\mathrm{H}} 1.81$ (s, H-19) and 0.95 (s, H-20). Its IR spectrum showed characteristic absorptions for $\mathrm{O}-\mathrm{H}$ stretching of carboxylic acid (3400 to $2400 \mathrm{~cm}^{-1}$ ), and an intense absorption characteristic of $\mathrm{C}=\mathrm{O}$ carboxyl stretching at $1705 \mathrm{~cm}^{-1}$. In addition, it showed absorptions at $1639 \mathrm{~cm}^{-1}$ of the $\mathrm{C}=\mathrm{C}$ stretching of alkenes and the correspondent out-of-plane bending at $755 \mathrm{~cm}^{-1}$. The ${ }^{1} \mathrm{H}$ and ${ }^{13} \mathrm{C} \mathrm{NMR}$ data (Table 2), suggested the structure of a tetracyclic diterpene with an ent-atisane backbone. According to the analysis of the spectral data obtained, and comparison with the literature data, it was possible to suggest that compound ICB8 was indeed the ent-3,4-secoatisa-4(18),16-dien3-oic acid, previously isolated from Excoecaria agallocha L. ${ }^{32}$ (Figure 1), isolated for the first time from C. blanchetianus.

Antimicrobial activity of extracts, fractions and diterpenes

The results of the antimicrobial assays performed with the hexane extracts from trunk bark, heartwood and roots of the three specimens of $C$. blanchetianus (CB1, CB4 and CB8) are shown in Table 1.

According to the results obtained, all extracts tested inhibited the bacterial growth. The RCB1, RCB4 and BCB8 
Table 2. ${ }^{1} \mathrm{H}$ and ${ }^{13} \mathrm{C}$ NMR data for compounds ICB1, ICB4 and ICB8 isolated from the hexane extract from roots of the three individual specimens of Croton blanchetianus

\begin{tabular}{|c|c|c|c|c|c|c|}
\hline \multirow{2}{*}{$\mathrm{C}$} & \multicolumn{2}{|c|}{$\mathrm{ICB} 1^{\mathrm{a}}$} & \multicolumn{2}{|r|}{$\mathrm{ICB} 4^{\mathrm{b}}$} & \multicolumn{2}{|c|}{$\mathrm{ICB} 8^{\mathrm{b}}$} \\
\hline & $\delta_{\mathrm{C}}$ & $\delta_{\mathrm{H}}($ mult., $J$ in $\mathrm{Hz})$ & $\delta_{\mathrm{C}}$ & $\delta_{\mathrm{H}}($ mult., $J$ in $\mathrm{Hz})$ & $\delta_{\mathrm{C}}$ & $\delta_{\mathrm{H}}($ mult., $J$ in $\mathrm{Hz}$ ) \\
\hline 1 & 36.4 & $\begin{array}{l}1.57(\mathrm{~m}, \mathrm{Ha}) \\
1.36(\mathrm{~m}, \mathrm{Hb})\end{array}$ & 36.1 & $2.22(\mathrm{~m}, 2 \mathrm{H})$ & 34.9 & $\begin{array}{l}1.95(\mathrm{c}, \mathrm{Ha}) \\
1.79(\mathrm{c}, \mathrm{Hb})\end{array}$ \\
\hline 2 & 28.6 & $\begin{array}{l}2.39(\mathrm{~m}, \mathrm{Ha}) \\
2.30(\mathrm{~m}, \mathrm{Hb})\end{array}$ & 30.3 & $\begin{array}{l}2.45(\mathrm{~m}, \mathrm{Ha}) \\
2.16(\mathrm{~m}, \mathrm{Hb})\end{array}$ & 29.9 & $\begin{array}{l}2.57(\mathrm{~m}, \mathrm{Ha}) \\
2.44(\mathrm{~m}, \mathrm{Hb})\end{array}$ \\
\hline 3 & 180.8 & - & 174.8 & - & 176.9 & - \\
\hline 4 & 147.7 & - & 147.8 & - & 148.3 & - \\
\hline 5 & 51.3 & 1.99 (brd, 12.0, H) & 47.3 & $2.49(\mathrm{~m}, \mathrm{H})$ & 51.2 & 2.07 (brd, 11.5, H) \\
\hline 6 & 20.8 & $\begin{array}{l}1.43(\mathrm{~m}, \mathrm{Ha}) \\
1.33(\mathrm{~m}, \mathrm{Hb})\end{array}$ & 25.8 & $\begin{array}{c}1.83(\mathrm{td}, 3.9,11.5, \mathrm{Ha}) \\
1.77(\mathrm{c}, \mathrm{Hb})\end{array}$ & 25.4 & $\begin{array}{l}1.72(\mathrm{c}, \mathrm{Ha}) \\
1.31(\mathrm{c}, \mathrm{Hb})\end{array}$ \\
\hline 7 & 32.6 & $1.55(\mathrm{~m}, 2 \mathrm{H})$ & 29.2 & $\begin{array}{c}2.81(\mathrm{dt}, 3.9,15.0, \mathrm{Ha}) \\
2.56(\mathrm{c}, \mathrm{Hb})\end{array}$ & 38.6 & $\begin{array}{l}1.29(\mathrm{brd}, 11.0, \mathrm{Ha}) \\
1.11(\mathrm{brt}, 11.0, \mathrm{Hb})\end{array}$ \\
\hline 8 & 49.1 & - & 126.3 & - & 33.9 & - \\
\hline 9 & 44.1 & $1.14(\mathrm{~d}, 11.8, \mathrm{H})$ & 142.0 & - & 44.4 & $1.39(\mathrm{c}, \mathrm{H})$ \\
\hline 10 & 39.3 & - & 41.7 & - & 40.3 & - \\
\hline 11 & 26.2 & $\begin{array}{c}1.81(\mathrm{~d}, 11.8, \mathrm{Ha}) \\
1.40(\mathrm{~m}, \mathrm{Hb})\end{array}$ & 112.5 & $7.20(\mathrm{~s}, \mathrm{H})$ & 28.8 & $\begin{array}{l}1.89(\mathrm{~m}, \mathrm{Ha}) \\
1.42(\mathrm{~m}, \mathrm{Hb})\end{array}$ \\
\hline 12 & 33.3 & $\begin{array}{l}1.31(\mathrm{~m}, \mathrm{Ha}) \\
1.26(\mathrm{~m}, \mathrm{Hb})\end{array}$ & 155.8 & - & 37.1 & 2.23 (brs, H) \\
\hline 13 & 43.8 & - & 121.6 & - & 27.7 & $\begin{array}{l}1.60(\mathrm{~m}, \mathrm{Ha}) \\
1.51(\mathrm{~m}, \mathrm{Hb})\end{array}$ \\
\hline 14 & 61.3 & $\begin{array}{l}1.49(\mathrm{~d}, 9.2, \mathrm{Ha}) \\
1.04(\mathrm{~d}, 9.2, \mathrm{Hb})\end{array}$ & 139.7 & - & 28.9 & $\begin{array}{l}1.62(\mathrm{~m}, \mathrm{Ha}) \\
0.97(\mathrm{c}, \mathrm{Hb})\end{array}$ \\
\hline 15 & 134.8 & $5.72(\mathrm{~d}, 5.0, \mathrm{H})$ & 137.0 & $6.73(\mathrm{dd}, 11.4,18.0, \mathrm{H})$ & 48.7 & $\begin{array}{l}2.03 \text { (brd, 13.8, } \mathrm{Ha}) \\
1.92 \text { (brd, 13.8, Hb) }\end{array}$ \\
\hline 16 & 137.0 & $5.49(\mathrm{~d}, 5.0, \mathrm{H})$ & 119.9 & $\begin{array}{l}5.57(\mathrm{dd}, 2.0,11.4, \mathrm{Ha}) \\
5.26(\mathrm{dd}, 2.0,18.0, \mathrm{Hb})\end{array}$ & 152.7 & - \\
\hline 17 & 25.0 & $1.01(\mathrm{~s}, 3 \mathrm{H})$ & 14.3 & $2.52(\mathrm{~s}, 3 \mathrm{H})$ & 105.7 & $\begin{array}{l}4.89(\mathrm{~s}, \mathrm{Ha}) \\
4.72(\mathrm{~s}, \mathrm{Hb})\end{array}$ \\
\hline 18 & 113.8 & $\begin{array}{l}4.87(\mathrm{~s}, \mathrm{Ha}) \\
4.68(\mathrm{~s}, \mathrm{Hb})\end{array}$ & 114.9 & $\begin{array}{l}4.99(\mathrm{~s}, \mathrm{Ha}) \\
4.84(\mathrm{~s}, \mathrm{Hb})\end{array}$ & 114.0 & $\begin{array}{l}4.96(\mathrm{~s}, \mathrm{Ha}) \\
4.87(\mathrm{~s}, \mathrm{Hb})\end{array}$ \\
\hline 19 & 23.9 & $1.75(\mathrm{~s}, 3 \mathrm{H})$ & 23.5 & $1.77(\mathrm{~s}, 3 \mathrm{H})$ & 24.3 & $1.81(\mathrm{~s}, 3 \mathrm{H})$ \\
\hline 20 & 18.7 & $0.77(\mathrm{~s}, 3 \mathrm{H})$ & 28.6 & $1.24(\mathrm{~s}, 3 \mathrm{H})$ & 18.3 & $0.95(\mathrm{~s}, 3 \mathrm{H})$ \\
\hline $\mathrm{O}-\mathrm{CH}_{3}$ & - & - & 51.8 & $3.56(\mathrm{~s}, 3 \mathrm{H})$ & - & - \\
\hline
\end{tabular}

${ }^{\mathrm{a}} 125 \mathrm{MHz}, \mathrm{CDCl}_{3}$; ${ }^{\mathrm{b}} 125 \mathrm{MHz}, \mathrm{C}_{5} \mathrm{D}_{5} \mathrm{~N}$; C: number of carbons in the compounds. ICBx: isolated from C. blanchetianus, $\mathrm{x}=1$ for specimen $1, \mathrm{x}=4$ for specimen $4, \mathrm{x}=8$ for specimen 8 .
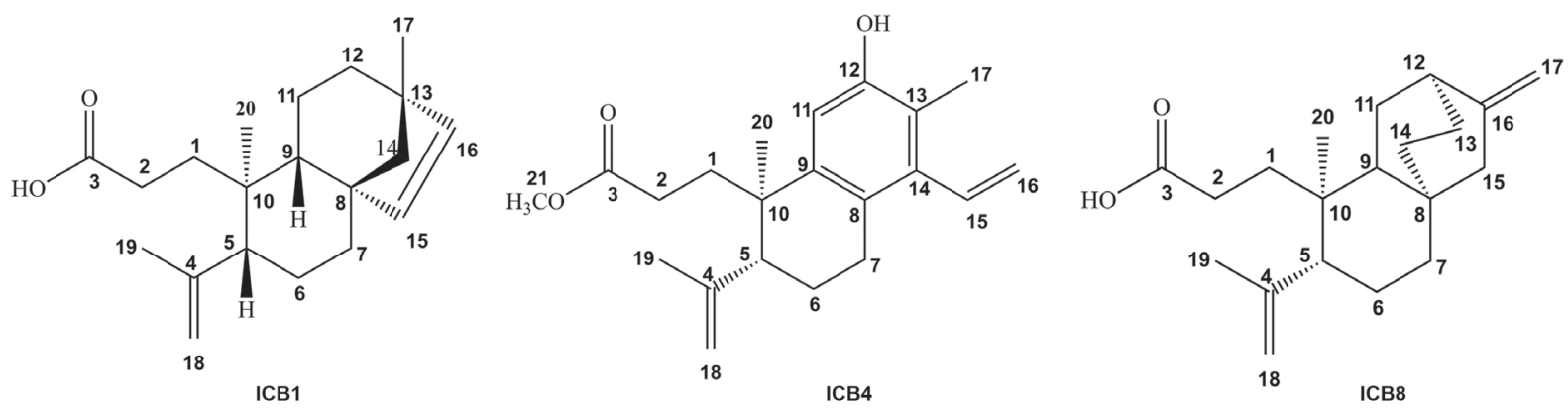

Figure 1. Structures of the seco-diterpenes isolated from the hexane extract from roots of the three individual specimens of C. blanchetianus. 
Table 3. MIC and MBC values of the acid fractions of CB1, CB4 and CB8 against S. mutans and S. parasanguinis

\begin{tabular}{|c|c|c|c|c|}
\hline \multirow{2}{*}{ Acid fraction } & \multicolumn{2}{|c|}{ S. mutans } & \multicolumn{2}{|c|}{ S. parasanguinis } \\
\hline & $\mathrm{MIC} /\left(\mu \mathrm{g} \mathrm{mL}^{-1}\right)$ & $\mathrm{MBC} /\left(\mu \mathrm{g} \mathrm{mL}^{-1}\right)$ & $\mathrm{MIC} /\left(\mu \mathrm{g} \mathrm{mL}^{-1}\right)$ & $\mathrm{MBC} /\left(\mu \mathrm{g} \mathrm{mL}^{-1}\right)$ \\
\hline AFCB1-HD2 & 31.2 & 62.5 & 31.2 & 125 \\
\hline AFCB1-D1 & 31.2 & 125 & 31.2 & 125 \\
\hline AFCB1-D3 & 250 & - & 250 & - \\
\hline AFCB1-DA1 & - & - & - & - \\
\hline AFCB1-AM & 125 & - & 125 & - \\
\hline AFCB4-HD2 & 62.5 & 250 & 62.5 & 125 \\
\hline AFCB4-D1 & 62.5 & 125 & 62.5 & 125 \\
\hline AFCB4-D3 & - & - & 500 & - \\
\hline AFCB4-DA1 & - & - & - & - \\
\hline AFCB4-AM & 500 & - & 500 & - \\
\hline AFCB8-HD1 & 7.8 & 7.8 & 15.6 & 15.6 \\
\hline AFCB8-D1 & 15.6 & 15.6 & 31.2 & 31.2 \\
\hline AFCB8-DA1 & 250 & - & - & - \\
\hline AFCB8-A & 250 & - & 500 & - \\
\hline AFCB8-AM & 500 & - & 250 & 500 \\
\hline
\end{tabular}

AFCBx: acid fractions of $C$. blanchetianus, $\mathrm{x}=1$ for specimen $1, \mathrm{x}=4$ for specimen 4 , and $\mathrm{x}=8$ for specimen $8 ; \mathrm{HD}: \mathrm{hexane} / \mathrm{CH}_{2} \mathrm{Cl}_{2} 50 \% ; \mathrm{D}: \mathrm{CH}_{2} \mathrm{Cl}_{2}$; DA: $\mathrm{CH}_{2} \mathrm{Cl}_{2} / \mathrm{EtOAc} 25 \%$; AM: EtOAc/MeOH; HD1: first fraction collected using hexane/ $\mathrm{CH}_{2} \mathrm{Cl}_{2} 50 \%$; $\mathrm{HD}$ 2: second fraction collected using hexane $/ \mathrm{CH}_{2} \mathrm{Cl}_{2} 50 \%$; D1: first fraction collected using $\mathrm{CH}_{2} \mathrm{Cl}_{2} ; \mathrm{D} 3$ : third fraction collected using $\mathrm{CH}_{2} \mathrm{Cl}_{2} ; \mathrm{DA} 1$ : first fraction collected using $\mathrm{CH}_{2} \mathrm{Cl}_{2} / \mathrm{EtOAc}$ 25\%. MIC: minimum inhibitory concentration; $\mathrm{MBC}$ : minimum bactericidal concentration.

extracts presented a bactericidal and bacteriostatic effect for both bacteria.

Considering the lowest inhibitory concentrations of the microbial growth, the hexane extracts from the roots were selected to perform the fractionation. In order to identify the compounds responsible for the antimicrobial action, the hexane extracts from roots were separated in acid and neutral fractions and then submitted to antibacterial assay.

Acid and neutral fractions showed antimicrobial activity, however, the acid fractions presented the lowest values of concentration with effective action. The antibacterial results for all acid fractions are presented in Table 3.

Fraction AFCB8 showed a more effective bactericidal and bacteriostatic effect, with the lowest concentrations, 7.8 and $15.6 \mu \mathrm{g} \mathrm{mL} \mathrm{m}^{-1}$, against both bacteria. The antibacterial results for the neutral fractions are presented in Table S3 (SI section).

After several fractionation steps, three diterpenes (ICB1, ICB4 and ICB8) were isolated and their antibacterial activity was determined (Table 4 ).

ICB1 presented the same MIC and MBC values against S. mutans $(410 \mu \mathrm{M})$, while against $S$. parasanguinis showed values of 206 and $410 \mu \mathrm{M}$, respectively. The AFCB 1 fraction, from which ICB1 was obtained, presented a four-fold inhibitory effect of ICB1 against $S$. mutans and
Table 4. MIC and MBC values of ICB1, ICB4, ICB8 diterpenes and chlorhexidine gluconate (positive control) against $S$. mutans and S. parasanguinis

\begin{tabular}{lcccc}
\hline \multirow{2}{*}{ Compound } & \multicolumn{2}{c}{ S. mutans } & \multicolumn{2}{c}{ S. parasanguinis } \\
\cline { 2 - 5 } & $\mathrm{MIC} / \mu \mathrm{M}$ & $\mathrm{MBC} / \mu \mathrm{M}$ & $\mathrm{MIC} / \mu \mathrm{M}$ & $\mathrm{MBC} / \mu \mathrm{M}$ \\
\hline ICB1 & 410 & 410 & 206 & 410 \\
ICB4 & 95 & 95 & 23.7 & 23.7 \\
ICB8 & 103 & 103 & 103 & 206 \\
Chlorhexidine & 2.1 & 18.4 & 1.1 & 2.1 \\
\hline
\end{tabular}

ICBx: isolated from $C$. blanchetianus, $\mathrm{x}=1$ for specimen $1, \mathrm{x}=4$ for specimen $4, x=8$ for specimen 8 . MIC: minimum inhibitory concentration; $\mathrm{MBC}$ : minimum bactericidal concentration.

two-fold increase against S. parasanguinis. However, MBC values remained the same for both bacteria.

Regarding to ICB4, the compound was obtained from the neutral fraction NFCB4-D2. ICB4 presented MIC and MBC values of $95 \mu \mathrm{M}$ against $S$. mutans, and $23.7 \mu \mathrm{M}$ against $S$. parasanguinis. ICB4 showed lower MIC values compared to NFCB4-D2. Moreover, NFCB4-D2 showed no bactericidal activity.

ICB8, isolated from the acid fraction AFCB8-D1, showed MIC and MBC values of $103 \mu \mathrm{M}$ against S. mutans. On the other hand, AFCB8-D1 showed MIC and MBC values lower compared to ICB8. The MIC 
values of AFCB8-D1 and ICB8 remained the same against $S$. parasanguinis, while MBC values of AFCB8-D1 were lower. Chlorhexidine gluconate was used as a positive control, presenting values ranging from 1.1 to $18.4 \mu \mathrm{M}$.

In this study, it was observed that all the hexane extracts from trunk bark, heartwood and roots of $C$. blanchetianus presented antimicrobial activity against $S$. mutans and $S$. parasanguinis, with concentrations ranging from 250 to $15.6 \mu \mathrm{g} \mathrm{mL}-1$. Our results corroborate with the study of Silva et al., ${ }^{33}$ where $C$. sonderianus Mull. ethanol extract inhibited dental caries-related bacteria growth, including S. mitis ATCC 9811. The authors emphasize the possibility of using this extract for oral pathologies treatment. ${ }^{34}$ The root hexane extract of $C$. sonderianus showed antibacterial activity against $B$. subtilis, $S$. aureus and Mycobacterium smegmatis, and antifungal activity against Candida albicans, Trichophyton mentagrophytes, and Helminthosporium sp. The reported action was attributed to the diterpenes hardwickiic acid and 3,4-secotrachylobanoic acid. ${ }^{34}$ The EtOAc extract from $C$. macrostachyus trunk bark inhibited the growth of Salmonella typhi, E. coli, Klebsiella pneumoniae, Enterobacter aerogenes, and Listeria monocytogenes, with MIC values ranging from 125 to $250 \mathrm{mg} \mathrm{mL}^{-1}$, being considered as a promising antimicrobial agent against important human pathogens. ${ }^{35}$

In this work, acid and neutral fractions were separated and it was observed that the acid fractions presented antimicrobial activity in smaller concentrations when compared to the neutral fractions (see Table S3, SI section). A previous study ${ }^{31}$ with the acid and neutral fractions of $C$. sonderianus showed that acid fraction had better antimicrobial activity against $B$. subtilis, $S$. aureus and Pseudomonas aeruginosa when compared to neutral fractions. Moreover, the authors isolated the compound ent-Beyer-15-en-18-oic acid that presented antimicrobial activity against $B$. subtilis. ${ }^{31}$

Croton species have been widely studied in relation to their volatile and non-volatile constituents. Many species are producers of a large number of substances belonging to the alkaloids, phenylpropanoids and terpenoids classes. ${ }^{36}$ The diterpenes isolated from C. blanchetianus showed clearly antimicrobial activity against $S$. mutans and $S$. parasanguinis. The diterpene class exhibits significant antimicrobial activity against Gram-negative, Gram-positive bacteria and yeasts. ${ }^{37,38}$ In addition, it is suggested that diterpenes interact in a non-specific way with the bacterial cell membrane, causing disruption of its structure. ${ }^{38}$ A casbane diterpene isolated from Croton nepetifolius Baill. showed potential antibacterial activity against several streptococci species related to caries, with MIC values ranging from 250 to $62.5 \mu \mathrm{g} \mathrm{mL}^{-1}$.
In addition, the ability to inhibit the formation of oral biofilms has been verified, therefore, being considered by the authors as a promising molecule on oral pathogens related to dental caries. ${ }^{39}$ Thus, the diterpenes isolated in this work have large potential for microbial therapy, however, toxicity tests are still required to determine the therapeutic index allowing the safety use.

\section{Conclusions}

In summary, in this study three 3,4-seco-diterpenes were isolated from the hexane extracts of roots of three individual specimens of $C$. blanchetianus Baill., including a novel diterpene 3,4-seco-beieren-3-oic acid (ICB1). Furthermore, the acid and neutral fractions, and the isolated compounds, showed a potential activity against two oral streptococci.

\section{Supplementary Information}

Supplementary data of the compounds ICB1, ICB4 and ICB8 (NMR, IR and HRMS spectra, Figures S1-S25) and Tables S1-S3 are available free of charge at http://jbcs.sbq.org.br as PDF file.

\section{Acknowledgments}

This study was supported by grants from the Conselho Nacional de Desenvolvimento Científico e Tecnológico (CNPq), Coordenação de Aperfeiçoamento de Pessoal de Nível Superior (CAPES) and Fundação Cearense de Apoio ao Desenvolvimento Científico e Tecnológico (FUNCAP). EHT and ERS are senior investigators of CNPq and members of the Brazilian Academy of Sciences.

\section{References}

1. Salatino, A.; Salatino, M. L. F.; Negri, G.; J. Braz. Chem. Soc. 2007, 18, 11 .

2. Palmeira Júnior, S. F.; Alves, V. L.; Moura, F. S.; Vieira, L. F. A.; Rev. Bras. Farmacogn. 2006, 16, 397.

3. Lima, L. R.; Pirani, J. R.; Biota Neotrop. 2008, 8, 2.

4. http://www.theplantlist.org/tpl1.1/record/kew-50556, accessed in November 2017.

5. http://www.theplantlist.org/tpl1.1/record/kew-50817, accessed in November 2017.

6. http://www.theplantlist.org/tpl1.1/record/kew-336462, accessed in November 2017.

7. Craveiro, A. A.; Silveira, E. R.; Braz Filho, R.; Mascarenhas, I. P.; Phytochemistry 1981, 20, 852.

8. Craveiro, A. A.; Silveira, E. R.; Phytochemistry 1982, 21, 2571. 
9. Silveira, E. R.; McChesney, J. D.; Phytochemistry 1994, 36, 1457.

10. Gomes, A. P. S.; Sales, M. F.; Melo, A. L.; Acta Bot. Bras. 2010 , 24,905 .

11. Oliveira, I. M. M.; Santos, H. S.; Sena Jr., D. M.; Cruz, B. G.; Teixeira, A. M. R.; Freire, P. T. C.; Braz-Filho, R.; Sousa, J. W.; Albuquerque, M. R. J. R.; Bandeira, P. N.; Bernardino, A. C. S. S.; Gusmão, G. O. M.; Bento, R. R. F.; J. Mol. Struct. 2015, 1099, 226.

12. Corlay, N.; Delang, L.; Girard-Valenciennes, E.; Neyts, J.; Clerc, P.; Smadja, J.; Guéritte, F.; Leyssen, P.; Litaudon, M.; Fitoterapia 2014, 97, 87.

13. Cordeiro, K. W.; Pinto, L. A.; Formagio, A. S.; Andrade, S. A. F.; Kassuya, C. A. L.; Freitas, K. C.; J. Ethnopharmacol. 2012, $143,331$.

14. Lin, H. C.; Kuo, Y. L.; Lee, W. J.; Yap, H. Y.; Biomed. Res. Int. 2016, DOI 10.1155/2016/3237586.

15. Kalayou, S.; Haileselassie, M.; Gebre-Egziabher, G.; Tiku, T.; Sahle, S.; Tadelle, H.; Ghezu, M.; Asian Pac. J. Trop. Biomed. 2012, 2, 516.

16. Brighenti, F. L.; Salvador, M. J.; Delbem, A. C.; Delbem, Á. C.; Oliveira, M. A.; Soares, C. P.; Freitas, L. S.; Koga-Ito, C. Y.; Caries Res. 2014, 48, 353.

17. Panda, S. K.; Mohanta, Z. K.; Padhi, L.; Park, Y. H.; Mohanta, T. K.; Bae, H.; Molecules 2016, 14, 21.

18. Nascimento, A. M.; Maria-Ferreira, D.; de Souza, E. F.; Sassaki, G. L.; Iacomini, M.; Werner, M. F.; Ciprane, T. R.; Int. J. Biol. Macromol. 2017, 95, 153.

19. Ximenes, R. M.; de Morais, N. L.; Cassundé, N. M.; Jorge, R. J.; dos Santos, S. M.; Magalhães, L. P.; Silva, M. R.; Viana, G. S. B.; Araújo, R. M.; de Sena, K. X.; de Albuquerque, J. F.; Martins, R. D.; J. Nat. Med. 2013, 67, 758.

20. Kathiravan, V.; Ravi, S.; Ashokkumar, S.; Velmurugan, S.; Elumalai, K.; Khatiwada, C. P.; Spectrochim. Acta, Part A 2015, 139, 200.

21. Jang, W. S.; Jyoti, M. A.; Kim, S.; Nam, K. W.; Ha, T. K.; Oh, W. K.; Song, H. Y.; J. Nat. Med. 2016, 1, 127.

22. Thuong, P. T.; Khoi, N. M.; Ohta, S.; Shiota, S.; Kanta, H.; Takeuchi, K.; Ito, F.; Anti-Cancer Agents Med. Chem. 2014, 14, 1051.

23. Lima, G. S.; Castro-Pinto, D. B.; Machado, G. C.; Maciel, M. A.; Phytomedicine 2015, 22, 1133.

24. Angélico, E. C.; Costa, J. G. M.; Rodrigues, O. G.; Lima, E. Q.; Medeiros, R. S.; BioFar 2011, 5, 44.
25. Alves, G. S.; Alves, J. M. F.; Martins, L. R. A.; Sousa, J. S.; Souto, J. S.; RVADS 2014, 9, 50.

26. Santos, F. A.; Jeferson, F. A.; Santos, C. C.; Silveira, E. R.; Rao, V. S. N.; Life Sci. 2005, 77, 2953.

27. Lima, G.; de Souza, T.; Freire, G. P.; Farias, D.; Cunha, A.; Ricardo, N.; de Morais, S.; Carvalho, A.; Parasitol. Res. 2013, 112, 1953.

28. Silva, F. S.; Albuquerque, U. P.; Costa Júnior, L. M.; Lima, A. S.; Nascimento, A. L. B.; Monteiro, J. M.; J. Ethnopharmacol. 2014, 155, 1332.

29. Bjarnsholt, G. F. D. M.; da Costa, A. C. V.; Garino, F.; Medeiros, R. S.; Madruga, M. S.; Neto, V. Q.; Braz. J. Microbiol. 2013, 44, 1189.

30. NCCLS, Approved Standard M7-A6; Methods for Dilution Antimicrobial Susceptibility Tests for Bacteria that Grow Aerobically; NCCLS: Wayne, PA, 2003.

31. McChesney, J. D.; Clark, A. M.; Silveira, E. R.; Pharm. Res. 1991, 8, 1243.

32. Li, Y.; Liu, J.; Yu, S.; Proksch, P.; Gu, J.; Lin, W.; Phytochemistry 2010, 71, 2124.

33. Silva, V. A.; Oliveira, C. R. M.; Freitas, A. F. R.; Costa, M. R. M.; Pessoa, H. L. F.; Pereira, M. S. V.; Rev. Odontol. UNESP 2011, 40, 69 .

34. McChesney, J. D.; Clark, A. M.; Silveira, E. R.; J. Nat. Prod. 1991, 54, 1625.

35. Obey, J. K.; Wright, A.; Orjala, J.; Kauhanen, J.; Kauhanen, C. T.; J. Pathog. 2016, DOI 10.1155/2016/1453428.

36. Randau, K. P.; Florêncio, D. C.; Ferreira, C. P.; Xavier, H. S.; Rev. Bras. Farmacogn. 2004, 14, 89.

37. Vasconcelos, M. A.; Arruda, F. V. S.; Santos, H. S.; Rodrigues, A. S.; Bandeira, P. N.; Albuquerque, M. R. J. R.; Cavada, B. S.; Teixeira, E. H.; Henriques, M.; Pereira, M. O.; Ind. Crops Prod. 2014, 61, 499.

38. Carneiro, V. A.; Santos, H. S.; Arruda, F. V. S.; Bandeira, P. N.; Albuquerque, M. R. J. R.; Pereira, M. O.; Henriques, M.; Cavada, B. S.; Teixeira, E. H.; Molecules 2011, 16, 190.

39. Sá, N. C.; Cavalcante, T. T. A.; Araújo, A. X.; dos Santos, H. S.; Albuquerque, M. R. J.; Bandeira, P. N.; da Cunha, R. M.; Cavada, B. S.; Teixeira, E. H.; Arch. Oral Biol. 2012, 57, 550.

Submitted: July 19, 2017 Published online: November 17, 2017 